SOUTHERN

Dipartimento di Economia e Finanza

EUROPE

RESEARCH

IN

ECONOMIC

UNIVERSITA

DEGLI STUDI DI BARI

STUDIES

\title{
Labour market access, family responsibilities and health perception of Italian women
}

\author{
Raffaella Patimo \& Chiara Mussida
}

SERIES Working PAPERS N. 04/2017

SERIES sono pubblicati a cura del Dipartimento di Economia e Finanza dell'Università degli Studi di Bari "Aldo Moro". I lavori riflettono esclusivamente le opinioni degli autori e non impegnano la responsabilità del Dipartimento. SERIES vogliono promuovere la circolazione di studi ancora preliminari e incompleti, per suscitare commenti critici e suggerimenti. $\mathrm{Si}$ richiede di tener conto della natura provvisoria dei lavori per eventuali citazioni o per ogni altro uso.
SERIES are published under the auspices of the Department of Economics and Finance of the University of Bari. Any opinions expressed here are those of the authors and not those of the Department. Often SERIES divulge preliminary or incomplete work, circulated to favor discussion and comment. Citation and use of these paper should consider their provisional character. 


\title{
Labour market access, family responsibilities and health perception of Italian women ${ }^{*}$
}

\author{
Raffaella Patimo ${ }^{\dagger}$, Chiara Mussida ${ }^{*}$ \\ Women gave "birth" to modern labour economics, \\ especially labour supply. Economists need variance to \\ analyse changes in behavioural responses, and women \\ provided an abundance of that. \\ Men, by and large, were not as interesting (...). \\ Claudia Goldin, T. Ely Lecture
}

\begin{abstract}
The aim of this paper is to highlight the determinants of female employment in Italy in recent years, when education, costumes, family composition and social and individual preferences for family and work have considerably changed from the past. Nevertheless, the difficulties Italian women still experience in planning and carrying out their (potential) professional and private life have no similar explanations in other countries.

We calculate the impact of several features of women's life in determining their employment and we find highly significant results which help to explain the situation. Furthermore, we investigate what shape the perception of their health status using the same variables. We find significant results also for explaining the health status of women through the (multiple) family burdens and the chance to have a job.
\end{abstract}

JEL classification: C25, E24, I10, J13, J21

Keywords: female employment, family burdens; health outcome

\footnotetext{
* The authors presented this paper at X Conference ESPANET Italia 2017, held at University of Bologna, Campus of Forlì, 21-23 September 2017.

† Dipartimento di Economia e Finanza, Università di Bari “A. Moro”, raffaella.patimo@uniba.it.

*Dipartimento di Scienze Economiche e Sociali, Università Cattolica del Sacro Cuore, Piacenza, chiara.mussida@unicatt.it.
} 


\section{Introduction}

The issues of access and attachment of women to labour market have been extensively studied for decades and cross cut with those several aspects of women's life that, from time to time, were held responsible both for variation or lack of it, such as marriage, motherhood, education, divorce, cultural context (Becker 1985, 1991; Bernhardt 1993; Brewster and Rindfuss 2000; Cramer 1980; Stycos and Weller 1967).

According to those studies, the main obstacles to women's increase in participation rates, first, and employment opportunities at a second stage, have been found in the reproductive role within the households and subsequent responsibility for childcare or family care in general.

In this paper we focus on Italy which is characterised by a fairly tight labour market: a high degree of inflexibility in wage determination, rigidity in hiring and firing practices and a very low participation by females in the labour force (OECD, 2009).

Italy's welfare system corresponds to the Mediterranean model (Sapir, 2006; Torrisi, 2011), traditionally characterised by strong job protection for the head of the household, and a low level of transfers among the working age population (Kuitto, 2011).

Furthermore, child and family related allowances are low, making the reconciliation of family and working roles difficult, especially for women (Del Boca, 2002; Del Boca et al., 2005; Del Boca and Pasqua, 2005; Figari et al., 2011).

The latest Global Gender Gap Index, calculated in the latest Global Gender Gap Report 2016 (World Economic Forum, 2016), ranked Italy at $50^{\text {th }}$ place out of the 144 analysed countries. This $50^{\text {th }}$ place underlies a very differentiated situation in the four sub-indexes (economic participation and opportunity, education attainment, health and survival, political empowerment). In particular, in the context of economic participation and opportunity $\left(117^{\text {th }}\right.$ rank), Italy faces a major disadvantage mainly attributable to women's participation in the labour market and gender pay inequality. This trend reflects the so-called breadwinner model, which, though dated and overtaken in many countries, unfortunately continues to negatively affect Italian women (Pascall and Lewis, 2004).

A quick glimpse to the reverse U-shaped curves for participation and employment of men and women helps to reveal the specific characteristics of the professional life of the two groups by gender. 
While that for men reaches its productivity and, often, remuneration peaks in the age class 3040 , that of women - descaled on the whole - experiences its top difficulties and obstacles in the same age class, being that the age of reproduction.

This has a twofold effect on women: the first one inspired by the wish to increase participation and employability which, on the other hand, implies to put off first childbearing or completely give up the idea of it. Mainly, these are highly educated women, who invested a lot in their capital accumulation and intend to yield the returns on that investment.

The second affects the group composed of low educated women who, in the worst scenario, do not even take into consideration the possibility to participate to the labour market anticipating, thus, the future they were going to experience under the traditional male breadwinner model. Since they expect to have the only role of mother and child (eventually own/partner's parents carer), they leave the labour market as soon as they form a family/have a child. If they ever were in the market before that. Education and the presence of family responsibilities play an important role for the selection of women into the labour market. There is evidence of positive selection of women into the workforce in European labour markets (i.e. Olivetti and Petrongolo, 2008). Women who stayed out of employment were those who would have earned the lowest returns from the market work because low educated and characterized by heavy family burdens.

It is all so evident that both effects above depicted become more pressing if the dependents (children, parents, siblings/other relative) they have in charge have an impairing disability/limitations in daily activities or two groups or more of dependents are cared for within the same family: children, disabled children, disabled household member, sick/disabled elderly.

With the intensification of the aging process of the population and the longer average span of life, Italian women, who were barely trying to bridge the gap from other European women in the workforce, are discovering that the responsibility of caring for disabled can last more than a decade, thereby making it even more difficult to access or stay in the labour market and possibly have strong consequences/effects in the health status of the caregivers, if not at the time of care, in their future (as a long-run effect on women health of caring).

The role men play in the field of family care, also very limited only to childcare in some countries, is generally restricted to providing economic support for the care of dependent parents (breadwinner model, even if in recent years men increased their housework share).

What are the consequences for women's employment opportunities and health status in Italy? 
The obstacles found impeding the access or the permanence in the labour market are generally indicated in the lack (or scarcity) of public or publicly funded family services and support (childcare; external day care for disabled; home support for disabled; lack of time synchronisation school and work time).

Actually, according to Esping-Andersen's welfare state taxonomy (1990), which classified countries in relation to the level of care given by the state and the family, Italy is identified as a familialistic system where the responsibility of individuals' care is mostly in the hands of family members and less on the state, due also to the scarcity of the provision of public services. Furthermore, Leitner (2003) identified differently familialism in EU member countries and classified Italy as an explicit familialism country, with an elevated component of gendered familialism. Here it comes the knot of the question: generally speaking, the "natural" provider of care, not only for small children, but also for all other type of dependents, is a woman: mother, daughter, daughter-in-law.

To address these issues, this paper aims to assess the impact of family burdens, such as the presence of dependents (presence and number of kids, presence of disabled household members, household size and composition), on women's employment opportunities/probabilities. In addition, we want to investigate whether and how the presence of family members with health and/or disability problems impacts female participation opportunities in the labour market and their perceived health status. Identifying the relationship between effective opportunities for women's participation and work and the burden of family care as a nursing activity - both dependent children and potential components with disabilities - can help explain the underlying high gap in the size of participation and economic opportunities (Global Gender Gap Index).

The subject of the analysis is Italy, using data from the European Union Statistics on Income and Living Conditions (EU-SILC) conducted by Eurostat, which contain both information on income, living conditions, social exclusion, housing, labour market status, demographic characteristics, education, as well as family characteristics, such as number of family members, and possibly presence of members with health and / or disability issues, allowing you to assess the degree of limitation in daily activities.

The availability of data from 2004 to the latest wave of 2015 will also allow us to assess the possible impact of the economic downturn on women's disadvantage.

The set-up of our paper is as follows. Section 2 offers a literature review. Section 3 describes data used and our empirical strategy to analyse both determinants of women employment 
probability and perceived health status. Section 4 sketches our main findings. Section 5 offers a discussion of our results. Section 6 concludes.

\section{Literature review}

The economists, and other social scientists, have extensively studied and written about the determinants of participation rates and employment patterns. They have encompassed studies on the causes of variation of female employment in relation to education attainment, childbearing and childcare (Del Boca \& Vuri, 2007) or more generally fertility (Ahn \& Mira 2002), institutional and territorial characteristics (Bratti et al., 2004; Cipollone et al., 2014), economic conjuncture (Duflo, 2012 but also Esping-Andersen on the secondary earner role of women, 2011), marriage negotiation power (Kooreman \& Kapteyn, 1990 and Lundberg et al., 1996), job attachment, health conditions (own's and relative's).

Therefore, one thing is sure: the interest in the topic has been steadily increasing and often on the top list of political debates. We therefore give a brief overview of the relevant literature so that we can better frame our study results and implications.

Many studies have proved the negative relation between domestic and family responsibilities and women's employment (Leigh, 2010; Munasinghe et al., 2008,). Education has been found as another major determinant of women's employment: by increasing women's expectations on wages, it affects fertility, i.e. either having/not having children and their number (Troske \& Voicu, 2009), and labour supply decisions (Gustaffsson \& Kenjoh, 2008).

Other studies show that the whole increase in women's labour force employment - and more generally participation - and attachment to work is due to structural modifications that influence the demand for women workers and similarly the relevant supply.

Several studies find that women's employment is positively related to policies alleviating the financial burden of child-rearing, both in the form of family-related subsidies (see, for example, Bardasi \& Gornick, 2003; Jaumotte, 2003;) and fiscal reductions (Eissa \& Liebman, 1996; Alesina et al., 2007) while other, especially for Italy, specify that the high cost of (limitedly) available childcare strongly (say infinitely) and negatively impact on female attitude to work and eventually employment (Del Boca \& Vuri, 2007). From another perspective, Lundin et al. (2008) give evidence that women's labour supply responds more elastically to the amount of public childcare facilities than to their cost.

In particular, countries with a welfare state more attentive to family needs (parental leave schemes or public childcare facilities) yield a larger involvement of women in paid labour 
(Berlinski \& Galiani, 2007; Anderson \& Levine, 1999; Attanasio, et al. 2008). Some authors compare the impact of monetary support versus the public provision of child-care services. Some found that among those countries, the ones supporting maternal employment through childcare facilities rather than child benefits have experienced both higher rates of women's labour supply and higher fertility rates (Apps \& Rees, 2004). Another strand of literature on the effect of family care on the probability to be employed has provided mixed results. Early studies provided no evidence of a negative relationship between elderly care and women's employment, but, more recently, new exercises have proven that caring for parents living outside the household and for co-living parents as well exerts a large negative impact on the labour supply of women (Ettner, 1996; Johnson \& Lo Sasso, 2000; Heitmueller, 2007). Direct and indirect health impacts have also to be taken into consideration. In particular, the psychophysical stress facing women in their multiple burden has been linked to adverse effects on physical and mental health (Henretta, Grundy and Harris, 2002; Do et al., 2014), and associated with higher economic costs (Henretta et al., 2002; Pierret, 2006; Wiemers and Bianchi, 2015; Suh, 2016), at individual and collective level.

A new cultural and social approach to the economic behaviour of the population relate employment decisions to cultural path dependence. One of the first attempts to model culture was made by Carroll, Rhee, and Rhee (1994) ${ }^{1}$ and has been followed since then by many authors, among which we refer to Fernandez \& Fogli (2009) and Blau et al. (2013) ${ }^{2}$. They found out that for some ethnicities, more than the actual surrounding context, it is the behaviour of past generation family women that impact on female workers' behaviours, tracking a path of persistence on an individual/family/ethnicity basis. It is acknowledged, though, that cultural norms on gender roles and welfare state developments are responsible for the general improvement in women's labour market outcomes in advanced countries in the last decades.

One main reason often produced to justify this high attention to women's labour performance is the one made, inter alia, by Del Boca and her co-authors $(2012$, p.17), referring to a widespread approach known as "womenomics" 3 ": if women reached men's employment rates, the economies would experience increases in GDP by 13\% in Eurozone area, by $16 \%$ in Japan and $22 \%$ in Italy.

This means that whatever revolution is considered being underway is not at all completed.

\footnotetext{
${ }^{1}$ Fernandez (2007), p. 311.

${ }^{2}$ This way of including the role of culture in an empirical analysis refers to the use of past generation indicators about working/fertility behaviour of women trying to match behaviours with subsequent generation women.

${ }^{3}$ Womenomics is a term first introduced by Kathy Matsui, Analyst at Goldman Sachs, Asia.
} 
In her inspiring lecture on the four phases of what she defines "quiet revolution"4, Claudia Goldin easily takes the readers to historical, sociological, economic and technological reasons of the ongoing transformation which began, in her own words, "in the late-1970s, when the birth cohorts of the late 1940s were in their early thirties, (... and continues) to the present, for the revolution is not over".

Esping-Andersen (2011), actually, talk about "incomplete revolution" as if, though quiet, this revolution has tripped into some invisible obstacles.

According to Del Boca and Rosina (2009), the revolution, at least in Italy, has been betrayed. By men only, but still betrayed. And those invisible obstacles we were mentioning above can easily be recognised in that "invisible production" supplied within Italian families. As calculated in a research by Fondazione Debenedetti (Boeri et al., 2008), using data on time use as divided within a family, the value of family production can be estimated in 432 billion Euro, more precisely 125 bn yielded by men and 308 bn by women. This value, correctly computed in national accounting, would raise the GDP by 33\% (Del Boca \& Rosina, 2009).

The double burden of work and family, which becomes triple (childcare) and even quadruple (elderly care), exacerbated by the meagre provision and support of public services, makes the adult women cohort one of the most fragile above all population and one of the most threatening burden for future population dynamics. Henceforth, the definitions of 'sandwich generation' (Miller, 1981) or 'double presence' (Balbo, 1979). This multi-generational and multi-role feature in daily life could become a major challenge which regards both the organization of time, between production and care activities, and of gender relations, especially in a country like Italy where it is the female individuals who tend to entirely provide the care and support work within the family (Del Boca, 2015). Not to mention the issues arising on the sustainability of welfare regimes, with its shrinking size in the public budget and the ageing process of population.

According to Goldin (2006), there is nothing revolutionary in a high participation rate: many low income/developing countries record high female participation rates. But this, alone, does not imply a more egalitarian, modern and efficient gender related labour market or society. To prove that a so defined revolution is going on, empirical research should study the dynamics of more fine-tuned indicators, such as: expectations of future employment for teen-aged girls; investment of young girls (their families) in human capital; determinants of life satisfaction; women's earnings to comparable men; participation rates with women with infants; lifetime

${ }^{4}$ Later published as Goldin (2006). 
participation; age at first marriage; fraction of life spent in marriage. To this we add the women perceived health status compressed, at various levels, between work (if they are so strong to survive to family events) and family duties and burdens (presence and number of children and disabled and relevant care).

\section{Data and Empirical Strategy}

\subsection{Data and Sample}

Our data are from the EU-SILC panel. It is a rotating panel survey based on harmonized methodology and definitions across most members of the European Union. ${ }^{5}$ The topics covered by the survey are living conditions, income, social exclusion, housing, work, demography, and education. We select data for Italy, where the survey is conducted on a yearly basis by the National Institute of Statistics (ISTAT) under the coordination of Eurostat. We analyze the time periods $2007 / 2010$ and 2011/2014, before and after the economic downturn.

Our samples include women aged between 25 and 64. In order to avoid to get mixed up with education enrolment and early retirement issues, we exclude from our analysis women under the age of 25 years and over the age of 64 years.

We also drop individuals with missing values for some variables used in the econometric analysis. Considering both the non-employed and the employed in the age range examined, 9,262 and 7,662 female observations remain over the periods 2007-2010 and 2011-2014, respectively. Table 1 reports summary statistics of the variables used in the econometric analysis computed on the samples of the women and disaggregated by time period.

Table 1. Descriptive statistics of individuals and households' characteristics in 2007-2010 and 2011-2014

\begin{tabular}{|l|l|l|l|l|}
\hline & Women in 2007-2010 & \multicolumn{2}{l|}{ Women in 2011-2014 } \\
\hline & Mean & Std. Dev. & Mean & Std. Dev. \\
\hline Employed & 53.4 & 49.9 & 56.9 & 49.5 \\
\hline Good health & 84.3 & 36.4 & 81.0 & 39.2 \\
\hline Age [25,34] & 18.4 & 38.7 & 15.0 & 35.7 \\
\hline Age [35,44] & 31.4 & 46.4 & 27.8 & 44.8 \\
\hline Age [45,54] & 28.0 & 44.9 & 32.3 & 46.7 \\
\hline Age [55,64] & 22.2 & 41.6 & 24.9 & 43.2 \\
\hline Primary education & 44.2 & 49.7 & 34.1 & 47.4 \\
\hline Secondary education & 35.7 & 47.9 & 42.1 & 49.4 \\
\hline Tertiary education & 20.1 & 40.1 & 23.8 & 42.6 \\
\hline Married & 71.8 & 45.0 & 66.0 & 47.4 \\
\hline Kids [0,3] & 8.5 & 29.2 & 6.6 & 26.3 \\
\hline Kids [3,6] & 11.1 & 34.0 & 10.4 & 33.0 \\
\hline Kids [6, 12] & 21.9 & 49.6 & 22.0 & 49.9 \\
\hline No disabled in household & 77.4 & 41.8 & 75.2 & 43.2 \\
\hline
\end{tabular}

\footnotetext{
${ }^{5}$ See Eurostat (2010) for further and technical details about the EU-SILC data.
} 


\begin{tabular}{|l|l|l|l|l|}
\hline Disabled in household & 15.4 & 36.1 & 18.2 & 38.6 \\
\hline Strongly disabled in household & 7.2 & 25.8 & 6.6 & 24.8 \\
\hline Household components & 2.01 & 0.52 & 3.17 & 1.23 \\
\hline Equivalized household mean income & 18,405 & 12,984 & 18,770 & 13,095 \\
\hline North & 42.1 & 49.4 & 47.6 & 49.9 \\
\hline Centre & 22.0 & 41.4 & 21.7 & 41.3 \\
\hline South & 35.9 & 48.0 & 30.7 & 46.1 \\
\hline Experience in paid work (years) & 13.76 & 10.72 & 15.38 & 11.20 \\
\hline $2007 / 2011$ & 25.0 & 43.3 & 25.0 & 43.3 \\
\hline $2008 / 2012$ & 25.0 & 43.3 & 25.0 & 43.3 \\
\hline $2009 / 2013$ & 25.0 & 43.3 & 25.0 & 43.3 \\
\hline $2010 / 2014$ & 25.0 & 43.3 & 25.0 & 43.3 \\
\hline Observations & \multicolumn{2}{|l}{9,292} & & 7,662 \\
\hline
\end{tabular}

Note: figures are in percentage, apart from age in years, household components in units, mean equivalized household income in Euro, and experience in paid work in years.

Source: Authors' elaborations on EU SILC 2007-2010 and 2011-2014 data.

The dependent variable of our main model (see Section 4.1) is the probability of being employed. We find that 53.4\% (56.9\%) of the active women are employed in 2007-2010 (2011-2014). The definitions of employment and non-employment do not match the ILO definition. In the EU-SILC questionnaire, the respondents are indeed asked to self-define the main economic status in the current year. ${ }^{6}$

The dependent variable for our further analysis is the perceived health status (variable PH020 in the EU-SILC code). It is a dummy indicator which equals one for good health or absence of chronic (long-standing) illness or condition, 0 for chronic disease.

We distinguish between four age groups: young women (25-34 years old), middle aged women (35-44 years old), and older women (45-54 years old), and (55-64 years old).

Educational variables are defined according to UNESCO's International Standard Classification of Education (ISCED). The EU-SILC distinguishes between education completed in the lower secondary stage (ISCED 0-2), upper secondary education (ISCED 3), and post-secondary or tertiary education (ISCED 5-7). In our samples we find an increasing levels of education for women between the two time periods. There is a reduction of women with primary education from $44.2 \%$ in $2007-2011$ to $34.1 \%$ in $2011-2014$, and an increase of secondary (from $35.7 \%$ in $2007-2010$ to $42.1 \%$ in $2011-2014$ ) and tertiary educational attainment rates (from $20.1 \%$ in $2007-2011$ to $23.8 \%$ in $2011-2014$ ).

Three dummy variables for the geographical area of residence (North, Center, and South) are included in the model specification. More than forty percent of the samples live in the North of Italy, followed by the South (more than 30\%) and the Center (more than 20\%). Indicator

\footnotetext{
${ }^{6}$ The variable PL030 contains information on the self-defined economic status. People are asked whether they are working, unemployed, students, in retirement, disabled, in military service, or fulfilling domestic task.
} 
for marital status and experience in paid work (measured in years) are included in the model, as likely to affect job opportunities. ${ }^{7}$

A set of covariates are used to capture the effects of some very important caring activities on women employment opportunities and perceived health in the second exercise). We included indicators for the presence and number of children of different age ranges, i.e. kids $[0,3]$ years old, kids $[3,6]$ years old, kids $[6,12]$ years old. It is important to distinguish between different age classes of children because these imply different intensities of caring activities. We account for the presence of disabled household members with different degrees of disability. The EU-SILC defines disability as activity limitations in daily activity of different degrees (variable PH030 in the EU-SILC code). We used indicators for the presence of household members with both some activity limitations and strong activity limitations. Similarly to what happens with kids, different degrees of disability presumably entail different intensity of caring duties.

We also offer information on the household size measured by the number of household components and on the equivalized household (mean) income as these might affect both the decision to work and the (perceived) health status of women. The equivalized-household income derives from total disposable household income (variable HY020 in the EU-SILC code), applying the within-household non-response inflation factor, HY025, and the equalized-household size, which gives each household member a specific weight. ${ }^{8}$ Income level is then deflated with the Consumer Price Index (CPI), gathered by ISTAT.

Finally, because we are using panel data, we included yearly dummy variables in our set of covariates.

\subsection{Empirical strategy}

Our first model entails the estimation of the determinants of women employment in Italy. We also worked on a second analysis of the determinants of women perceived health status. The focus of this work is on the effects of caring activities on women employment (and perceived health status). First, caring activities refer to the presence of dependent children in the household and, as explained above, we have the opportunity to distinguish between the

\footnotetext{
${ }^{7}$ Work experience is not included in our second analysis of the determinants of women perceived health status.

${ }^{8}$ To reflect differences in household's size and composition, the total net household income is divided by the number of 'equivalent adults', using a standard equivalence scale, i.e., the modified OECD scale. In detail, this scale gives a weight to all members of the household (and then adds these up to arrive at the equivalized household size): 1.0 to the first adult; 0.5 to the second and each subsequent person aged 14 and over; 0.3 to each child under 14.

For additional details, see http://ec.europa.eu/eurostat/ statistics-explained /index.php /Glossary:Equivalised disposable income.
} 
presence and number of kids aged between 0 and 3, between 3 and 6, and between 6 and 12 . Second, we account for possible caring due to the presence of disabled household members with different degrees of activity limitations (some activity limitations and strong activity limitations). Finally, the household composition, i.e., number of household components, and household wealth, i.e. equivalized household income, also offer important insights.

We estimate the determinants of being employed (on the samples of women, see Table 1), i.e. our main model, and the determinants of women perceived health status using pooled probit regression models for the time windows 2007-2010 and 2011-2014. The choice of a binary regression model reflects the need to obtain a simplified representation of labour market participation of women to employment. With a binary representation we can split our samples in a more convenient and simple manner.

In terms of employment, our dependent variable is 1 if the woman is employed and 0 otherwise. For the health status analysis, our dependent variable is 1 for good health and 0 for chronic disease.

A concise description of these models and our estimation strategy follows. For the sake of brevity and clarity we will refer to our main model for employment probability.

For binary outcome data the dependent variable $y$ takes one of two values. We let $y=1$ with probability $\mathrm{p}$, and $\mathrm{y}=0$ with probability $1-\mathrm{p}$. In our investigations y equals 1 if a women employed and 0 otherwise.

A probit model is formed by parameterizing the probability $\mathrm{p}$ to depend on a regressor vector $\mathrm{x}$ and a $\mathrm{K} \times 1$ parameter vector $\beta$. It is a single-index form model with conditional probability given by

$$
p_{i} \equiv \operatorname{Pr}\left[y_{i} \quad=1 \mid x\right]=F\left(x_{i}^{\prime} \beta\right)
$$

where $F($.$) is a specified function. To ensure that 0 \leq y \leq 1$ it is natural to specify $F($.$) to be a$ cumulative distribution function. The probit model assumes that $F($.$) in eq. (1) is the standard$ normal cumulative distribution function (such as for the error, which is standard normal distributed) and specifies the conditional probability as

$$
p=\Phi\left(x_{i}^{\prime} \beta\right)=\int_{-\infty}^{x_{i}^{\prime} \beta} \phi(z) d z
$$


where $\Phi($.$) is the standard normal cumulative distribution function. Model parameters are$ estimated using Maximum Likelihood. ${ }^{9}$ For all our sets of estimates we calculated the marginal effects, which will be commented later in the paper.

\section{Results}

\subsection{First Model: employment}

This subsection reports and comments on the impact of the regressors on women employment probability with particular emphasis on caring activities. Table 2 reports the estimates for our main model. We show coefficients and, since these are not directly interpretable, we calculated the marginal effects. For continuous variables, like the number of kids, household components, and equalized household income, marginal effects give the impact (in \%) of an infinitesimal change of these variables on the dependent variable (employment probability). For dummy variables, marginal effects give the impact (in percentage points) of a change from zero to one of the dummy variable on the dependent variable (employment probability). Employment probabilities are positively associated to education, i.e. possible positive selection of women into employment (see Introduction). In both periods the employment probability of women with tertiary education are 21.3 percentage points higher compared to those of women with primary education. Employment opportunities are also higher for women residing into the North and Centre, compared to the South of Italy. Years of experience in paid work increase women employability. The opportunities are instead low for married and older women (aged 45 or above).

Moving to caring responsibilities, having kids reduces the employment probability especially if those aged between 0 and 3 years (-6.2 \% in 2007-2010, and $-6.4 \%$ in 2011-2014). The negative impact does not change with the economic downturn. The presence of disabled, especially with strong activity limitations, decreases the employment opportunities of women and the impact reduces from 2007-2010 to 2011-2014. Estimates of our main model suggest that caring activities negatively and significantly affect employment probability of women and the effect does not change with the economic downturn.

Finally, women in largest household (by number of household members) and with low equivalized household income have reduced employment opportunities.

\footnotetext{
${ }^{9}$ A detailed technical description of the Maximum Likelihood method in this context can be found in Cameron and Trivedi (2005, ch. 15).
} 
Table 2. Determinants of women employment probability in Italy

\begin{tabular}{|c|c|c|c|c|c|c|}
\hline & Coef. & Std. Err. & Mgl. Eff. & Coef. & Std. Err. & Mgl. Eff. \\
\hline & \multicolumn{3}{|c|}{$2007 / 2010$} & \multicolumn{3}{|c|}{$2011 / 2014$} \\
\hline \multicolumn{7}{|c|}{ Dependent variable: employment probability } \\
\hline Secondary education & $0.501^{* * *}$ & 0.036 & $0.133^{* * *}$ & $0.415^{* * *}$ & 0.039 & $0.120^{* * *}$ \\
\hline Tertiary education & $0.802^{* * *}$ & 0.044 & $0.213^{* * *}$ & $0.734^{* * *}$ & 0.048 & $0.213^{* * *}$ \\
\hline Good health & $0.121^{* * *}$ & 0.044 & $0.032^{* * *}$ & $0,200^{* * *}$ & 0,043 & $0,058^{* * *}$ \\
\hline Married & $-0,253^{* * *}$ & 0.039 & $-0.067^{* * *}$ & $-0.278^{* * *}$ & 0.039 & $-0.080^{* * *}$ \\
\hline Centre & $0.163^{* * *}$ & 0.042 & $0.043^{* * * *}$ & $0.135^{* * *}$ & 0.047 & $0.039^{* * *}$ \\
\hline North & $0.208^{* * *}$ & 0.037 & $0.055^{* * *}$ & $0.110^{* * *}$ & 0.041 & $0.032^{* * *}$ \\
\hline Experience in paid work (years) & $0.080^{* * *}$ & 0.002 & $0.021^{* * *}$ & $0.065^{* * *}$ & 0.002 & $0.019^{* * *}$ \\
\hline Kids $[0,3]$ & $-0.232^{* * *}$ & 0.052 & $-0.062^{* * *}$ & $-0.220^{* * * *}$ & 0.062 & $-0.064^{* * *}$ \\
\hline Kids $[3,6]$ & $-0.117^{*}$ & 0.046 & $-0.031^{*}$ & -0.048 & 0.052 & -0.014 \\
\hline Kids $[6,12]$ & $-0.094^{* * *}$ & 0.034 & $-0.025^{* * *}$ & -0.054 & 0.037 & -0.016 \\
\hline Disabled in household & $-0.144^{* * *}$ & 0.044 & $-0.038^{* * *}$ & $-0.080^{*}$ & 0.044 & $-0.023^{* * *}$ \\
\hline Strongly disabled in household & $-0.242^{* * *}$ & 0.064 & $-0.064^{* * *}$ & $-0.116^{*}$ & 0.069 & $-0.033^{*}$ \\
\hline Age $[35,44]$ & 0.012 & 0.047 & 0.003 & 0.002 & 0.054 & 0.000 \\
\hline Age $[45,54]$ & $-0.526^{* * *}$ & 0.055 & $-0.140^{* * *}$ & $-0.326^{* * *}$ & 0.059 & $-0.094^{* * *}$ \\
\hline Age [55.64] & $-2.155^{* * *}$ & 0.072 & $-0.573^{* * *}$ & $-1.551^{* * *}$ & 0.073 & $-0.449^{* * *}$ \\
\hline Household components & $-0.117^{* * *}$ & 0.033 & $-0.031^{* * *}$ & $-0.030^{*}$ & 0.016 & $-0.009^{*}$ \\
\hline Equivalized household mean income & $0.013^{* * *}$ & 0.001 & $0.003^{* * *}$ & $0.014^{* * *}$ & 0.002 & $0.004^{* * *}$ \\
\hline $2008 / 2012$ & -0.002 & 0.044 & 0.000 & -0.061 & 0.046 & -0.018 \\
\hline $2009 / 2013$ & $-0.092^{*}$ & 0.044 & $-0.025^{*}$ & $-0.109^{*}$ & 0.046 & $-0.031^{*}$ \\
\hline $2010 / 2014$ & $-0.104^{*}$ & 0.044 & $-0.028^{*}$ & $-0.088^{*}$ & 0.047 & $-0.025^{*}$ \\
\hline Constant & -0.702 & 0.095 & & $-0.818^{* * *}$ & 0.089 & \\
\hline Observations & & \multicolumn{2}{|c|}{9,292} & \multicolumn{3}{|c|}{7,662} \\
\hline Log likelihood & & \multicolumn{2}{|c|}{$-4349,828$} & \multicolumn{3}{|c|}{$-3912,378$} \\
\hline Pseudo $R^{2}$ & & \multicolumn{2}{|c|}{0.3223} & \multicolumn{3}{|c|}{0.2528} \\
\hline
\end{tabular}

\subsection{Second model: health status analysis}

Table 3 reports the results of our health status analysis on the determinants of women perceived health status (dependent variable). The same regressors as for the first model (Table 2) are used with the exception of experience in paid work. We find that being employed, young, (secondary) high educated, married, and residing in the South of Italy positively affect the subjective health status of women. Living in larger and wealthier households (by number of components and equivalized household income) also exerts positive effects on women health status. The relevance and sign are maintained after the crisis.

As far as caring activities are concerned, the presence of kids aged from 0 to 6 years does not exert a relevant impact, whereas having children from 6 to 12 years of age positively affect women perceived health (1.8\% in 2007-2010 and 2.2\% in 2011-2014). This might be partly due to the fact that 6 years is the starting school age and this might alleviate the caring activities of children aged from 6 and over. Caring of disabled negatively affects women's health in both time periods. According to our findings from the employment model and to 
those of health status analysis, caregiving activity negatively affects not only employment probability but also (and significantly) women's perceived health status.

Table 3. Determinants of women perceived health status in Italy

\begin{tabular}{|c|c|c|c|c|c|c|}
\hline & Coef. & Std. Err. & Mgl. Eff. & Coef. & Std. Err. & Mgl. Eff. \\
\hline & \multicolumn{3}{|c|}{$2007 / 2010$} & \multicolumn{3}{|c|}{$2011 / 2014$} \\
\hline \multicolumn{7}{|l|}{ Dependent variable (good) health status } \\
\hline Employed & $0.114^{* * *}$ & 0.037 & $0.026^{* * *}$ & $0.189^{* * *}$ & 0.038 & $0.047^{* * *}$ \\
\hline Secondary education & $0.106^{* * *}$ & 0.039 & $0.024^{* * *}$ & $0.161^{* * *}$ & 0.041 & $0.040^{* * *}$ \\
\hline Tertiary education & 0.009 & 0.048 & 0.002 & 0.077 & 0.052 & 0.019 \\
\hline Married & $0.113^{* * *}$ & 0.040 & $0.026^{* * *}$ & 0.058 & 0.042 & 0.015 \\
\hline North & $-0.239^{* * *}$ & 0.039 & $-0.055^{* * *}$ & $-0.226^{* * *}$ & 0.043 & $-0.056^{* * *}$ \\
\hline Centre & -0.058 & 0.046 & -0.013 & $-0.158^{* * *}$ & 0.050 & $-0.040^{* * *}$ \\
\hline Kids $[0,3]$ & 0.042 & 0.065 & 0.010 & -0.092 & 0.076 & -0.023 \\
\hline Kids $[3,6]$ & -0.020 & 0.055 & -0.005 & -0.072 & 0.063 & -0.018 \\
\hline Kids $[6,12]$ & $0.079^{*}$ & 0.042 & $0.018^{*}$ & $0.088^{*}$ & 0.043 & $0.022^{*}$ \\
\hline Disabled in household & $-0.289^{* * *}$ & 0.043 & $-0.066^{* * *}$ & $-0.450^{* * *}$ & 0.044 & $-0.112^{* * *}$ \\
\hline Strongly disabled in household & $-0.457^{* * *}$ & 0.058 & $-0.105^{* * *}$ & $-0.437^{* * *}$ & 0.067 & $-0.109^{* * *}$ \\
\hline Age $[35,44]$ & $-0.272^{* * *}$ & 0.055 & $-0.062^{* * *}$ & $-0.386^{* * *}$ & 0.068 & $-0.097^{* * *}$ \\
\hline Age $[45,54]$ & $-0.348^{* * *}$ & 0.058 & $-0.080^{* * *}$ & $-0.673^{* * *}$ & 0.067 & $-0.168^{* * *}$ \\
\hline Age $[55,64]$ & $-0.568^{* * *}$ & 0.060 & $-0.130^{* * *}$ & $-0.832^{* * *}$ & 0.071 & $-0.208^{* * *}$ \\
\hline Household components & $0.054^{* * *}$ & 0.017 & $0.012^{* * *}$ & $0.137^{* * *}$ & 0.018 & $0.034^{* * * *}$ \\
\hline Equivalized household mean income & $0.003^{*}$ & 0.002 & $0.001^{*}$ & $0.005^{* * *}$ & 0.002 & $0.001^{* * *}$ \\
\hline $2008 / 2012$ & 0.003 & 0.046 & 0.001 & $0.163^{* * *}$ & 0.048 & $0.041^{* * *}$ \\
\hline $2009 / 2013$ & 0.004 & 0.046 & 0.001 & $0.172^{* * *}$ & 0.048 & $0.043^{* * *}$ \\
\hline $2010 / 2014$ & -0.037 & 0.046 & -0.008 & $0.242^{* * *}$ & 0.049 & $0.061^{* * * *}$ \\
\hline Constant & $1.138^{* * *}$ & 0.082 & & $0.864^{* * *}$ & 0.093 & \\
\hline Observations & & \multicolumn{2}{|c|}{9,292} & \multicolumn{3}{|c|}{7,662} \\
\hline Log likelihood & & \multicolumn{2}{|c|}{$-3852,206$} & \multicolumn{3}{|c|}{$-3432,148$} \\
\hline Pseudo $R^{2}$ & & \multicolumn{2}{|c|}{0.0479} & \multicolumn{3}{|c|}{0.0774} \\
\hline
\end{tabular}

\section{Discussion}

Our findings confirm that women having (whatever) family responsibilities are strongly affected in their employability. Having a burden which consists of children to rear, especially those $0-3$ years (but also in the other two age classes considered, 3-6; 6-12) negatively and significantly affects the probability of having a job. Same sign and same high significance hold for the other types of burdens: the presence of disabled (both with limited or strong disabilities) has a negative impact on female work. As a confirmation of how unbalancing can be a simple event of having a family in terms of right and opportunity to work, being married and the very number of family components also affect the probability of working for an Italian woman.

When considering education levels or household (equivalized) income, the relation becomes positive, but this implies a clear risk for women with lower education and with lower 
household income of perpetrating their conditions through their life course and, most probably, in that of their daughters (i.e. future generation persistence).

It is not surprising, then, that the presence of children and disabled in the family, much more than the family itself, constitutes a considerable obstacle to women's labour market access. What is more important is that this negative impact can affect not only the employability of a woman but also, in turn, her reproductive preferences, though not by their choice (path persistence and adaptive expectations of younger cohorts).

The fact that being in an age class over 45 is also among the negative determinants of employment, in that age when the sandwich syndrome (see above, $\S 2$ ) is highly present, is a clear call for public action and corrections.

A good health (perceived) status, furthermore, contributes to increase the probability to work of a female.

Taking into consideration also the health conditions family member who works and gives care can add to the debate on how much and for how many reasons a public intervention is highly recommendable. Considerations are to be made not only on a pure economic basis of computing the worth to the contribution made in the family production, but also on the basis of efficiency purposes of public budget use. The relevant savings implied by an informal, unpaid, stressed caregiver cannot be borne only by those households who, by the unforeseeable events of life, end up with the triple burden of children (temporary at the beginning of professional life), elderly (at the peak/end of professional life), disabled family members (most likely all life long)

So, our attempt to sketch the nature of the shaping factors of the health status of female individuals suggests that private life preferences and decisions (family formation, career) and other circumstances affecting private life and citizen status (health condition, presence of disabled, chronic illness of ageing family members) cannot be treated separately and need to be monitored and accompanied for reasons of cost-effectiveness and sustainability of a decent job and the right of family, not to mention the solution to one of the most threatening demographic challenge: the ageing of population and the low fertility rates who will fuel further this negative dynamics.

The studies on time use (Istat, 2012) - who picture Italian women working, on the whole, more than other European women and more than Italian men - help us in disentangling one fundamental reason of these existing and obsolete obstacles to a balanced work-family life. The descriptive data on the use of time show us a strong specialization of the tasks of Italian men and women, with a marked decrease in remunerated working hours for mothers and a 
parallel increase of those of fathers, unlike in any other European country, where the decision of working for the market seems independent of family composition and burdens.

It is well accounted for, in these data, that the presence of children further accentuates gender imbalance Increasing roles specialization. The sharp decline in hours of paid job of Italian mothers, and on the contrary, the rise in hours of paid work for the fathers, just after the birth of children, is not found in any other country. Italy is also the only country where female employment does not increase once the children are grown up. This effect, while partly being attributable to a cohort effect, is significantly present only in Italy. This situation reflects the difficulties of Italian women trying to reconcile maternity and work, brought by both cultural factors (i.e. traditional gender roles with poor participation in housework on behalf of the fathers), and structural constraints, such as the rigidity of the labour market and the limited supply of child care services.

The road to a more equal set of opportunities of market access, family responsibilities and good health maintenance and perception passes by a true and aware sharing of family and house burdens between partners and also among adult members of the family. The paternity leave is only of 2 days. The parental leave up to 10 months (up to 3 years for parents of children with strong disability) for both parents are, so far, at best a palliative: until the collaboration of fathers/men will be socially stigmatised and generally unacceptable by peers and employers, other measures - differentiating universally the work conditions of women with family burdens - have to be found to make even what past behaviours and resilient culture have made profoundly uneven in economic, social and personal terms.

\section{Conclusions}

A sizeable disadvantage of women's labour market participation is observed in many European labour markets. This trend partly reflects the so-called breadwinner model, which, though dated and overtaken in many countries, unfortunately continues to negatively affect Southern Europe. This is especially true for low educated women and for those characterized by heavy family burdens. These burdens include, for instance, childcare, care of household members affected by activity limitations/disability. The responsibility of caring for disabled can last more than a decade, thereby making it even more difficult to access or stay in the labour market and possibly have strong consequences/effects in the health status of the caregivers, if not at the time of care, in their future (as a long-run effect on women health of caring). 
Based on these considerations, we analysed the determinants of women employment probability and health status by pinpointing the effects of the presence of family responsibilities/burdens (presence of number of children and disabled in the household). We analyzed Italy, a country in which child- and family-related allowances are low and unevenly spread, making the reconciliation of family and working roles difficult, especially for women. We find that caring activities negatively affect the probability of successful access (finding a job) of women to the labour market and their perceived health status as well.

\section{References}

Ahn, N. \& Mira, P. (2002), "A note on the changing relationship between fertility and female employment rates in developed countries", Journal of Population Economics 15(4), pp. 667-682.

Alesina, A., A. Ichino and L. Karabarbounis (2007), "Gender Based Taxation and the Division of Family Chores", NBER Working Paper 13638, National Bureau of Economic Research, Cambridge, MA.

Anderson, P.M. and P.B. Levine (1999), "Child Care and Mothers' Employment Decisions", NBER Working Paper No. 7058, National Bureau of Economic Research, Cambridge, MA.

Apps, P. and A. Rees (2004), "Fertility, Taxation and Family Policy", Scandinavian Journal of Economics 106(4): 745-763.

Attanasio, O., H. Low and V. Sanchez-Marcos (2008). "Explaining Changes in Female Labor Supply in a Life-Cycle Model", American Economic Review 98(4): 1517-1552.

Bardasi, E. and J.C. Gornick (2003), "Women and Part-time Employment: workers' choices' and wage penalties in five industrialized countries", in Garcia, B., R. Anker and A. Pinnelli (eds), Women in the labor market in changing economies: Demographic issues, Oxford: Oxford University Press, pp. 209-44.

Becker, G. (1981), A treatise on the family, Cambridge, USA: Harvard University Press.

Becker, G. S. (1985). Human Capital, Effort, and the Sexual Division of Labor. Journal of Labor Economics, 3(2), 33-58.

Berlinski, S. and S. Galiani (2007), "The effect of a large expansion of pre-primary school facilities on preschool attendance and maternal employment", Labor Economics 14(3): 665-680.

Bernhardt, E. M. (1993). Fertility and Employment. European Sociological Review, 9(1), 2542.

Blau, F. D., Kahn, L. M., Liu, A. Y. H., \& Papps, K. L. (2013). The transmission of women's fertility, human capital, and work orientation across immigrant generations. Journal of Population Economics, 26(2), 405-435.

Boeri, T., Burda, M., \& Kramarz, F. (2008). Working hours and job sharing in the EU and USA: are Europeans lazy? Or Americans crazy?. Oxford University Press.

Brewster, K., \& Rindfuss, R. (2000). Fertility and women's employment in industrialized countries. Annual Review of Sociology, 26(1), 271-296. 
Brilli, Y., Del Boca, D., \& Pronzato, C. D. (2016). Does child care availability play a role in maternal employment and children's development? Evidence from Italy. Review of Economics of the Household, 14(1), 27-51.

Cameron A.C., Trivedi P.K. (2005), Microeconometrics: Methods and Applications, Cambridge, Cambridge University Press.

Carroll, C. D., Rhee, B. K., \& Rhee, C. (1994). Are there cultural effects on saving? Some cross-sectional evidence. The Quarterly Journal of Economics, 109(3), 685-699.

Cipollone, A., Patacchini, E., \& Vallanti, G. (2014). Female labour market participation in Europe: novel evidence on trends and shaping factors. IZA Journal of European Labor Studies, 3(1), 18.

Cramer, J. C. (1980). Fertility and female employment: Problems of causal direction. American Sociological Review, 45(2), 167-190.

Del Boca D., Mencarini L., Paqua S. (2012), "Valorizzare le donne conviene". Ruoli di genere nell'economia italiana. Collana "Contemporanea"

Del Boca, D. (2002). Do child care costs affect labor supply?. Centre for Household Income, Labour, Demographic Economics, Working Paper, (18).

Del Boca, D. (2015), Child care arrangements and labor supply, Inter-American Development Bank.

Del Boca, D. and Pasqua, S. (2005), Labor supply and fertility in Europe and the US, in Boeri, T., Del Boca, D. and Pissarides, C. (Eds),Women at Work: An Economic Perspective, Chapter 8, Oxford University Press, Oxford, pp. 125-153.

Del Boca, D., \& Flinn, C. J. (2014). Household behavior and the marriage market. Journal of Economic Theory, 150, 515-550.

Del Boca, D., \& Vuri, D. (2007). The mismatch between employment and child care in Italy: the impact of rationing. Journal of Population Economics, 20(4), 805-832.

Del Boca, D., Pasqua, S. \& Pronzato, C. (2005), Fertility and employment in Italy, France, and the UK, Labour, 19(S1): 51-77.

Del Boca, D., Pasqua, S., \& Pronzato, C. (2008). Motherhood and market work decisions in institutional context: a European perspective. Oxford Economic Papers, 61(suppl_1), i147-i171.

Do, E. K., Cohen, S. A., \& Brown, M. J. (2014), Socioeconomic and demographic factors modify the association between informal caregiving and health in the Sandwich Generation, BMC public health, 14(1), 1-8.

Duflo, E. (2012). Women empowerment and economic development. Journal of Economic Literature, 50(4), 1051-1079

Eissa, N. and J.B. Liebman (1996), "Labor supply response to the Earned Income Tax Credit", Quarterly Journal of Economics, Cambridge, MA: MIT Press, Vol. 111(2), 605-637

Esping-Andersen, G. (2011). La rivoluzione incompiuta. Donne, famiglie, welfare. Bologna, il Mulino.

EUROSTAT. (2010). Description of Target Variables: Cross-sectional and Longitudinal. EUSILC 065/2010.

Fernandez, R. (2007). Alfred Marshall lecture. Women, work, and culture. Journal of the European Economic Association, 5 (2-3), 305-332. 
Figari, F., Paulus, A. and Sutherland, H. (2011), Measuring the size and impact of public cash support for children in cross-national perspective, Social Science Computer Review, 29(1): 85-102.

Fogli A. \& Fernandez R., (2009), "Culture: An Empirical Investigation of Beliefs, Work, and Fertility," American Economic Journal: Macroeconomics, American Economic Association, vol. 1(1), pages 146-77, January

Givord, P., \& Marbot, C. (2015), Does the cost of child care affect female labor market participation? An evaluation of a French reform of childcare subsidies, Labour Economics, 36, 99-111.

Goldin, C. (2006), "The Quiet Revolution that Transformed Women's Employment, Education, and Family," American Economic Review 96(2):1-21.

Henretta, J., Grundy, E. \& Harris, S. (2002), The influence of socioeconomic and health differences on parents' provision of help to adult children: a British-United States comparison, Ageing and Society, 22, 441-458.

ISTAT (2012), Uso del tempo e ruoli di genere. Tra lavoro e famiglia nel ciclo di vita. Argomenti, n. 43.

Jaumotte, F. (2003), "Labour force participation of women: empirical evidence on the role of policy and other determinants in OECD countries", OECD Economic Studies, 51-108.

Kooreman P. and A. Kapteyn (1990) "On the empirical Implementation of some theoretic Models of Household Labour Supply" Journal of Human Resources. 25

Kuitto, K. (2011), More than just money: patterns of disaggregated welfare expenditure in the enlarged Europe, Journal of European Social Policy, 21(1): 348-364.

Künemund, H. (2006), Changing welfare states and the "sandwich generation": Increasing burden for the next generation?, International Journal of Ageing and Later Life, 1(2), 11-29.

Leigh, A. (2010), "Informal care and labor market participation", Labor Economics 17(1): 140-49.

Leigh, A. (2010), "Informal care and labor market participation", Labor Economics 17(1): $140-49$.

Leitner, S. (2003), Varieties of familialism: The caring function of the family in comparative perspective, European Societies, 5(4), 353-375.

Lundberg, S.J., Pollak, R.A., and T.J. Wales (1996), "Do Husbands and Wives Pool Their Resources? Evidence from the United Kingdom Child Benefit," Journal of Human Resources, 32(4): 463:480

Miller, D. (1981), The 'sandwich' generation: adult children of the aging, Social Work, 26(5), 419-423.

Munasinghe, L., T. Reif and A. Henriques (2008), "Gender gap in wage returns to job tenure and experience", Labor Economics 15(6): 1296-316

OECD (2009), Employment Outlook, OECD, Paris.

Olivetti, C., Petrongolo, B., 2008. Unequal pay or unequal employment? A cross-country analysis of gender gaps. Journal of Labor Economics,26 (4), 621-654.

Pagani, L., \& Marenzi, A. (2008), The labor market participation of sandwich generation Italian women, Journal of Family and Economic Issues, 29(3), 427-444.

Pascall, G. and Lewis, J. (2004), Emerging gender regimes and policies for gender equality in a wider Europe, Journal of Social Policy, 33(3): 373-394. 
Pierret, C. R. (2006), Sandwich Generation: Women Caring for Parents and Children, The Monthly Labor Review., 129, 3. Quarterly Journal of Economics, Cambridge, MA: MIT Press, Vol. 111(2), pp. 605-637

Sapir, A. (2006), Globalization and the reforms of European social models, Journal of Common Market Studies, 44(2): 369-390.

Sironi, M., Barban, N. \& Impicciatore, R. (2015), Parental social class and the transition to adulthood in Italy and the United States, Advances in Life Course Research, 26, 89-104.

Stycos, J., \& Weller, R. (1967). Female Working Roles and Fertility. Demography, 4(1), 210217.

Suh, J. (2016), Measuring the "sandwich": Care for children and adults in the American Time Use Survey 2003-2012, Journal of family and economic issues, 1-15.

Torrisi, G. (2011), Redistributive policies and recipients: an empirical analysis, Journal of Academic Research in Economics, 2(1): 109-124.

Viitanen, T. K. (2005), Cost of Childcare and Female Employment in the UK, Labour, 19(S1), 149-170.

Wiemers, E. E., \& Bianchi, S. M. (2015), Competing demands from aging parents and adult children in two cohorts of American women, Population and Development Review, 41(1), 127-146. 